Article

\title{
Scale-Up Synthesis and Identification of GLYX-13, a NMDAR Glycine-Site Partial Agonist for the Treatment of Major Depressive Disorder
}

\author{
Wenchao Li ${ }^{1,+}{ }^{\dagger}$, Jingjian Liu ${ }^{1,+}{ }^{+}$, Minghua Fan ${ }^{1}$, Zhongtang $\mathrm{Li}^{1}{ }^{1}$, Yin Chen ${ }^{2}$, Guisen Zhang ${ }^{2, *}$, \\ Zhuo Huang ${ }^{1}$ and Liangren Zhang ${ }^{1, *}$ \\ 1 State Key Laboratory of Natural and Biomimetic Drugs, School of Pharmaceutical Sciences, \\ Peking University, Beijing 100191, China; wenchaoli@bjmu.edu.cn (W.L.); jingjian0828@163.com (J.L.); \\ 15122180567@163.com (M.F.); lizhongtang@bjmu.edu.cn (Z.L.); huangz@hsc.pku.edu.cn (Z.H.) \\ 2 Jiangsu Nhwa Pharmaceutical Co., Ltd., 69 Democratic South Road, Xuzhou 221116, Jiangsu, China; \\ chenyin091400@126.com \\ * Correspondence: george_gs@163.com (G.Z.); liangren@bjmu.edu.cn (L.Z.); Tel.: +86-27-87792235 (G.Z.); \\ +86-10-8280-2567 (L.Z.); Fax: +86-27-87792170 (G.Z.); +86-10-8280-5063 (L.Z.) \\ + These authors contributed equally to this paper.
}

Received: 21 March 2018; Accepted: 21 April 2018; Published: 24 April 2018

\begin{abstract}
GLYX-13, a NMDAR glycine-site partial agonist, was discovered as a promising antidepressant with rapidly acting effects but no ketamine-like side effects. However, the reported synthetic process route had deficiencies of low yield and the use of unfriendly reagents. Here, we report a scaled-up synthesis of GLYX-13 with an overall yield of $30 \%$ on the hectogram scale with a column chromatography-free strategy, where the coupling and deprotection reaction conditions were systematically optimized. Meanwhile, the absolute configuration of precursor compound of GLYX-13 was identified by X-ray single crystal diffraction. Finally, the activity of GLYX-13 was verified in the cortical neurons of mice through whole-cell voltage-clamp technique.
\end{abstract}

Keywords: GLYX-13; NMDA receptor; chromatography-free synthesis; crystal structure; whole-cell voltage-clamp

\section{Introduction}

Clinical studies have demonstrated that the $N$-methyl-D-aspartate receptor (NMDAR) antagonist ketamine has rapid antidepressant effects on patients with treatment-resistant depression. This finding suggests that depression can be associated with deficits in the glutamatergic system [1]. NMDAR represents the core of the post-synaptic density (PSD) [2], and plays a critical role in the development of diverse central nervous system (CNS) disorders [3]. Meanwhile, chronic inflammatory disorders that can be modulated by NMDAR are associated with an increased prevalence of MDD [4-6]. Recently, several drug candidates which bind with the glycine site of NMDAR have entered clinical trials and presented neuroprotective and anti-depressant effects [7]. GLYX-13, a C-terminal amidated tetrapeptide (Thr-Pro-Pro-ThrNH ${ }_{2}$ ), is a NMDAR glycine-site partial agonist and a promising drug candidate for the treatment of major depressive disorders (MDD). Enhanced release of brain-derived neurotrophic factor (BDNF) is required for the rapid and sustained antidepressant effects of GLYX-13 [8]. Due to its rapid onset effect, GLYX-13 has been granted breakthrough therapy designation by the Food and Drug Administration (FDA) and it is currently in phase III clinical trials $[9,10]$. In addition, different to other antidepressants in clinical use, GLYX-13 does not show psychotomimetic side effects [11]. Although there are a number of studies on the bioactivity of GLYX-13 [10,12-14], there are limited reports regarding to the synthetic route of GLYX-13. Weiguo et al. have published the first synthetic route of 
GLYX-13 in a patent [15], however, it has drawbacks of low overall yield, and the use of unfriendly reagents and operating conditions, etc. On the basis of the synthetic route reported by the patent, herein, an improved synthetic route to GLYX-13 was designed by a fragment coupling approach commonly used in peptide synthesis. The procedure, that is suitable for scaled-up synthesis, successfully avoids the drawbacks of the original synthetic route. The three aspects of the reaction conditions were optimized as follows: replacement of unsuitable reagents, improvement of the coupling approach and simplification of the post-processing steps.

\section{Results and Discussion}

GLYX-13 is a tetrapeptide, so its synthesis could be performed by " $2+2$ " fragment-coupling strategy (Figure 1). In this approach, $\mathrm{N}$-Cbz-L-Thr amide, Fmoc-L-Pro, Fmoc-O- ${ }^{\mathrm{t}} \mathrm{Bu}-\mathrm{L}-\mathrm{Thr}$ and L-Pro benzyl ester hydrochloride was used as starting materials, and intermediates $\mathbf{3}$ and $\mathbf{5}$ were firstly synthesized as the key dipeptide segments.

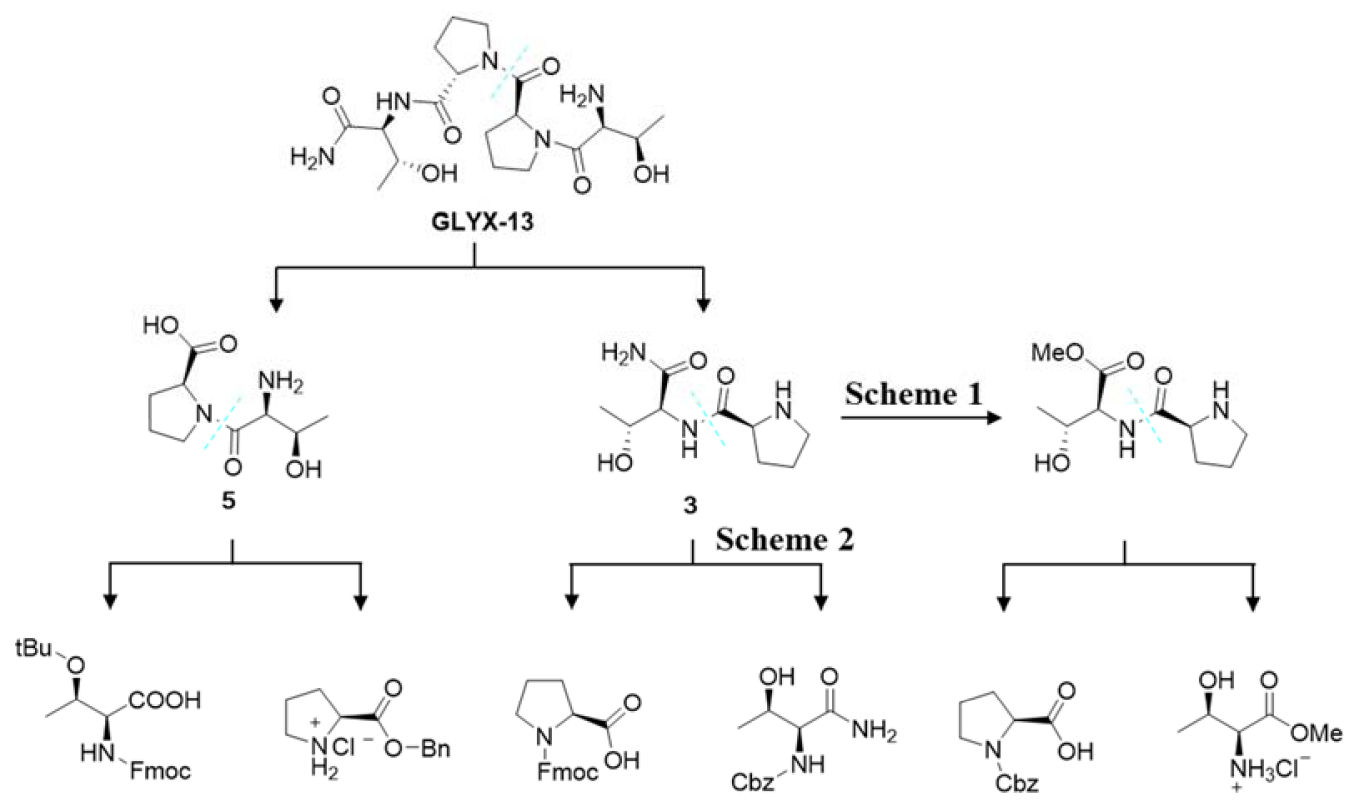

Figure 1. Retrosynthesis of GLYX-13.

\subsection{Synthesis of Dipeptide Fragment 3}

Initially, we intended to obtain dipeptide 3 in accordance with the procedure presented in Scheme 1. $\mathrm{N}$-Cbz-Pro-OH was employed as starting material to produce the intermediate 3 via three steps including a coupling reaction [16-19] yielding intermediate 1a [15], aminolysis of the methyl ester yielding intermediate 2a [20-22] and catalytic hydrogenation yielding 3 (Scheme 1). However, the aminolysis reaction furnished intermediate $\mathbf{2} \mathbf{a}$ in poor yield $(40 \%)$. Meanwhile, intermediate 3 synthesized via this procedure tended to be a yellowish oily liquid, which was inconvenient for industrial production.

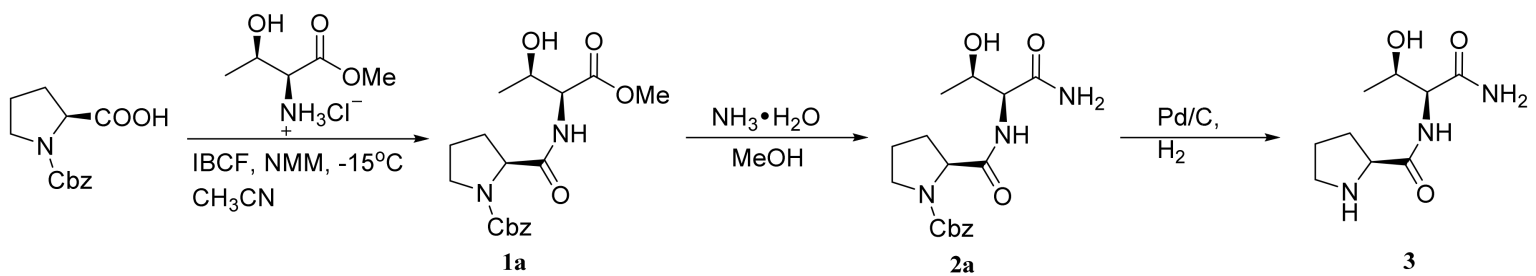

Scheme 1. The initial intended synthetic route of intermediate 3. 
To improve the synthetic procedure of intermediate 3, a commercially available compound, $\mathrm{N}-\mathrm{Cbz}$-Thr amide, was used to generate threonine amide hydrochloride (1b) by catalytic hydrogenation. Compound $\mathbf{1 b}$ could be easily purified by the process of acidification and crystallization. Moreover, by crystallization from DMF-water accompanied with the addition of the corresponding seed crystals, intermediate $\mathbf{2} \mathbf{b}$ was obtained in a high purity (Scheme 2).

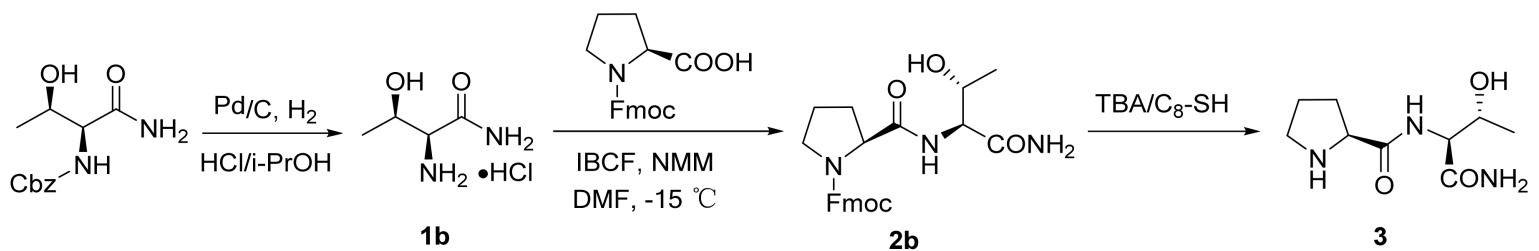

Scheme 2. The optimized synthetic route of intermediate 3.

The reported method to remove the Fmoc group of intermediate $\mathbf{2 b}(20 \%$ piperidine in DMF) was tedious. After several different deprotection methods were tried, such as $\mathrm{AlCl}_{3} /$ toluene, DMSO $\left(120{ }^{\circ} \mathrm{C}\right)$, and catalytic hydrogenation [23-29] tert-butyl amine (TBA) was chosen as the optimal deprotection agent accompanied by 1-octanethiol $\left(\mathrm{C}_{8}-\mathrm{SH}\right)$ added as an efficient scavenger of dibenzofulvene, a reactive by-product derived from Fmoc removal [24]. TBA is volatile and the by-product was easily removed by washing with ethyl acetate. Finally, intermediate 3 was obtained as white solid by recrystallization from ethyl acetate/ethanol (1:1). In brief, the optimized synthetic route shown in Scheme 2 afforded both high yield and involved easy handling, which were particularly suitable for scaled-up synthesis.

\subsection{Synthesis of Dipeptide Segment 5}

In the synthetic route reported by Weiguo et al., intermediate 5 was synthesized by a two-step reaction including coupling reaction and deprotection of a methyl ester, in which Fmoc-Thr $\left({ }^{\mathrm{t}} \mathrm{Bu}\right)-\mathrm{OH}$ and proline methyl ester hydrochloride served as starting materials (Scheme 3). However, the highly hygroscopic proline methyl ester hydrogen chloride and the inefficient coupling reaction mediated by isobutyl chloroformate (IBCF) led to a low yield of the desired product. Moreover, the hydrolysis of the methyl ester caused undesired removal of the Fmoc group.<smiles>C[C@H](NC(=O)OC(C)(C)C)[C@@H](C)OC(C)(C)C</smiles><smiles>COC(=O)[C@H]1CCCN1</smiles><smiles>CC(=O)N[C@H](C(=O)N1CCC[C@H]1C(C)=O)[C@@H](C)OC(C)(C)C</smiles>

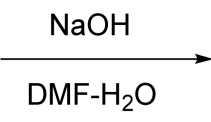

DMF- $\mathrm{H}_{2} \mathrm{O}$<smiles>CC(C)O[C@H](NC(=O)OCc1ccccc1)C(=O)N1CCC[C@H]1C(=O)O</smiles>

5

Scheme 3. The initial synthetic route to intermediate 5 .

To overcome the above problems, a new procedure was designed by us, in which proline benzyl ester hydrochloride is not highly hygroscopic and IBCF was replaced by pivaloyl chloride (PivCl) (Scheme 4). In the following coupling reaction, imidazole was found to be a cost-efficient coupling agent accompanied with minimal impurities as detected by TLC [30-42]. During the coupling condition optimization in the synthesis of 4, the combination of EDCI with coupling additives, such as HOBt, DMAP, HOSu and HONp, was also tested but these coupling conditions generated a number of by-products. Similarly, other coupling agents such as $\mathrm{TsCl}$ and cyanuric chloride gave 4 in low yield and with a lot of impurities. As for the reaction solvent, the mixture of THF and DCM was chosen due to the excellent solubility of both starting materials (Table 1). 
<smiles>CC(OC(C)(C)C)C(NP)C(=O)O</smiles><smiles>O=C(OCc1ccccc1)C1CCCN1</smiles><smiles>CC(=O)N[C@H](C(=O)N1CCCC1C(=O)OCc1ccccc1)C(C)OC(C)(C)C</smiles>

4

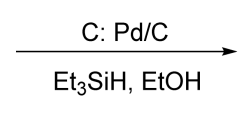<smiles>CC(NC(C(=O)N1CCCC1C(=O)O)C(C)OC(C)(C)C)C(=O)O</smiles>

Scheme 4. Improved synthetic route of 5.

Table 1. Coupling reaction conditions optimization in the synthesis of 4 .

\begin{tabular}{ccccc}
\hline Entry & Method & Base & Reaction Solvent $^{\mathbf{a}}$ & Impurity $^{\mathbf{b}}$ \\
\hline 1 & EDCI/HOBt & DIPEA & DCM & Obvious \\
2 & EDCI/DMAP & DIPEA & DCM & Obvious \\
3 & EDCI/HOSu & DIPEA NaHCO 3 & DCM/THF & Obvious \\
4 & EDCI/HONp & DIPEA NaHCO & DCM/THF & Obvious \\
5 & TsCl & NMM & DCM, THF, ACN & Obvious \\
6 & TsCl & NMI & DCM, THF, ACN & Obvious \\
7 & Cyanuric chloride & NMM & ACN/Acetone/DMF & Obvious \\
8 & Cyanuric chloride & NMM & THF/toluene & Trace \\
9 & PivCl & TEA & THF/DCM & Trace \\
10 & PivCl & Imidazole & THF/DCM & Trace \\
\hline
\end{tabular}

${ }^{\text {a }}$ THF/DCM was the optimal reaction solvent; ${ }^{\text {b }}$ Impurity was detected by TLC.

Because of 4 had a low melting temperature and was difficult to isolate in a solid form, the crude oil liquid of 4 was used in the deprotection step after simple extraction. Removal of the benzyl group of 4 was chemoselective (Table 2) [43-46], and the impurities were minimized when triethylsilane and ethanol were used as the hydrogen donor and reaction solvent, respectively.

Isolation of 5 from the reaction mixture was carried out by a combination of neutralized extraction and recrystallization (Figure 2). Partitioning between ethyl acetate and saturated $\mathrm{NaHCO}_{3}$ aqueous solution was efficient for elimination of the most organic impurities. Additional hexane washes was needed to ensure that the residual levels of organic impurities in the crude product after neutralized extraction were minimal, and evaporation of ethyl acetate afforded 5 as yellowish oily liquid. Recrystallization from hexane/ethanol (6:1) gave 5 as a white solid.

Table 2. Reaction conditions optimization of benzyl deprotection in the synthesis of 5 .

\begin{tabular}{cccc}
\hline Entry & Method & Reaction Solvent & Yield (\%) \\
\hline 1 & $\mathrm{Pd} / \mathrm{C}, \mathrm{H}_{2}$ & $\mathrm{MeOH}$ & - \\
2 & $\mathrm{Pd} / \mathrm{C}, \mathrm{H}_{2}$ & $\mathrm{EtOH}$ & - \\
3 & $\mathrm{Pd} / \mathrm{C}, \mathrm{HCOONH} H_{4}$ & $\mathrm{MeOH}$ & - \\
4 & $\mathrm{Pd} / \mathrm{C}, \mathrm{HCOOH}$ & $\mathrm{MeOH}$ & - \\
5 & $\mathrm{Pd} / \mathrm{C}, \mathrm{Et}_{3} \mathrm{SiH}$ & $\mathrm{MeOH}$ & $65 \%$ \\
6 & $\mathrm{Pd} / \mathrm{C}, \mathrm{Et}_{3} \mathrm{SiH}$ & $\mathrm{EtOH}$ & $68 \%$ \\
\hline
\end{tabular}

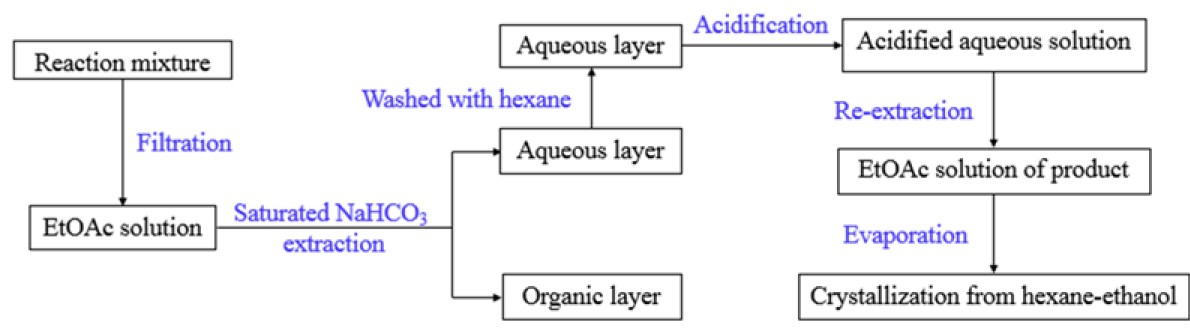

Figure 2. Schematic representation of the isolation of 5 from the reaction mixture. 


\section{3. " $2+2$ " Fragment Coupling Reaction and the Preparation of GLYX-13}

As we already had success with PivCl as the optimal coupling agent in the synthesis of 4, PivCl was directly used as coupling agent in the " $2+2$ " fragment coupling reaction while N-methyl morpholine (NMM) was used as base (Scheme 5). In fact, the coupling reaction of 3 and 5 performed well in these coupling conditions. However, the resulting product was also an oily liquid and inappropriate for purification, so the liquid was directly used in the next step reaction after simple extraction. In the deprotection reaction, the tert-butyl ether of 6 was removed using TFA as deprotecting reagent in the original synthetic route. In order to replace TFA with a less corrosive reagent, several deprotection agents were tried, such as $85 \%$ phosphoric acid solution, zinc bromide and sodium iodide/cerium chloride [47-49]. Finally, zinc bromide was chosen as the optimal reagent for its low cost, environmentally-friendly properties and convenient post-processing.

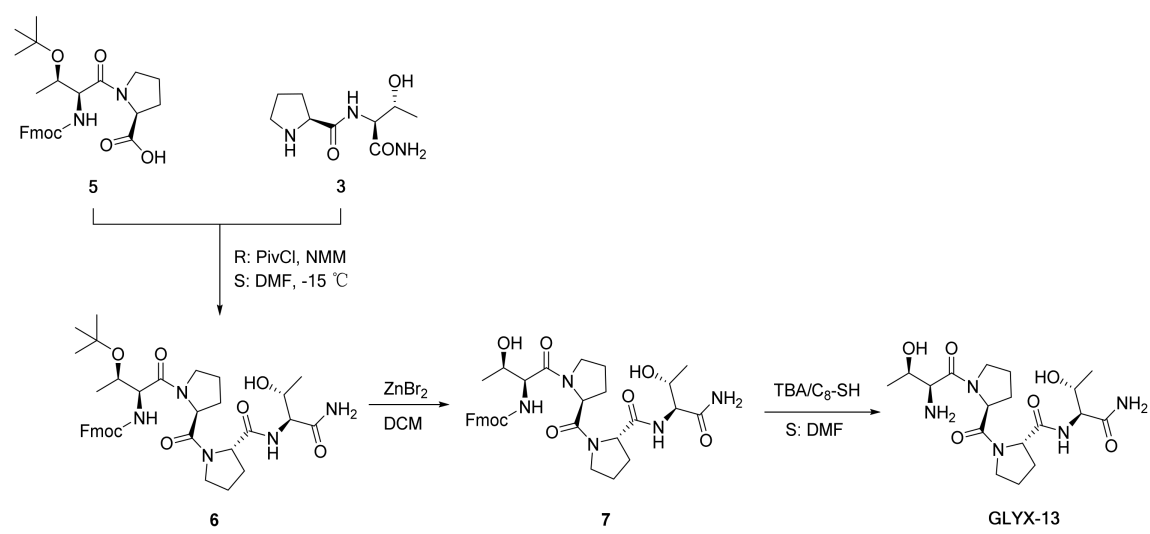

Scheme 5. " $2+2$ " fragment coupling reaction and final two deprotection reactions.

In addition, isolation of 7 from the reaction mixture was fairly simple, i.e., slow addition of water into the reaction mixture while stirring. Then, 7 was crystallized as a white solid with a high purity. Finally, the deprotection of 7 was similar to that of $\mathbf{3}$, and the work-up also used the same procedures, to afford GLYX-13 as a hygroscopic white solid.

\subsection{X-ray Single Crystal Diffraction and Powder Diffraction of $\mathbf{7}$}

GLYX-13 contains six chiral centers, and our plan was to resolve its absolute configuration by X-ray crystal diffraction, however, GLYX-13 proved hard to crystallize although various solvents were tried. We found that 7, which had the same absolute configuration as GLYX-13, formed crystals much easier than GLYX-13, and the X-ray crystal diffraction showed the right absolute configuration. (Figure 3 and Table S1). Furthermore, a simulated diagram was generated from the single crystal diffraction data by Mercury software. The good match of the experimental diagram with the simulated diagram demonstrated the optical purity of 7 (Figure 4).

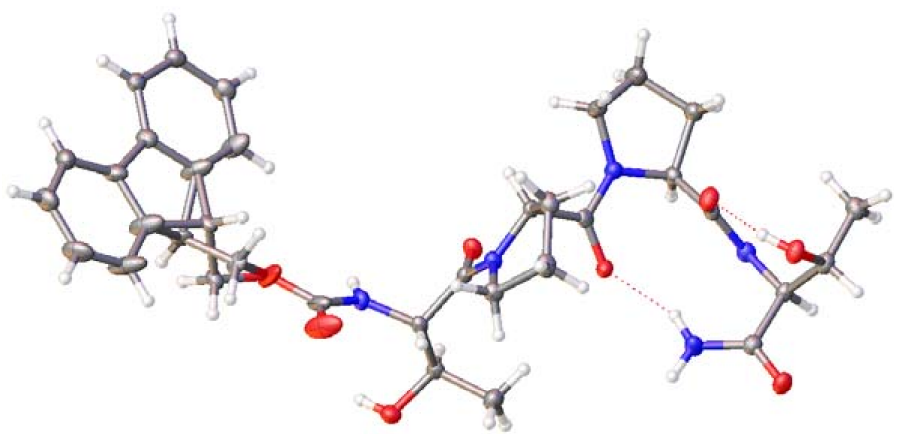

Figure 3. Crystal structure of 7. 


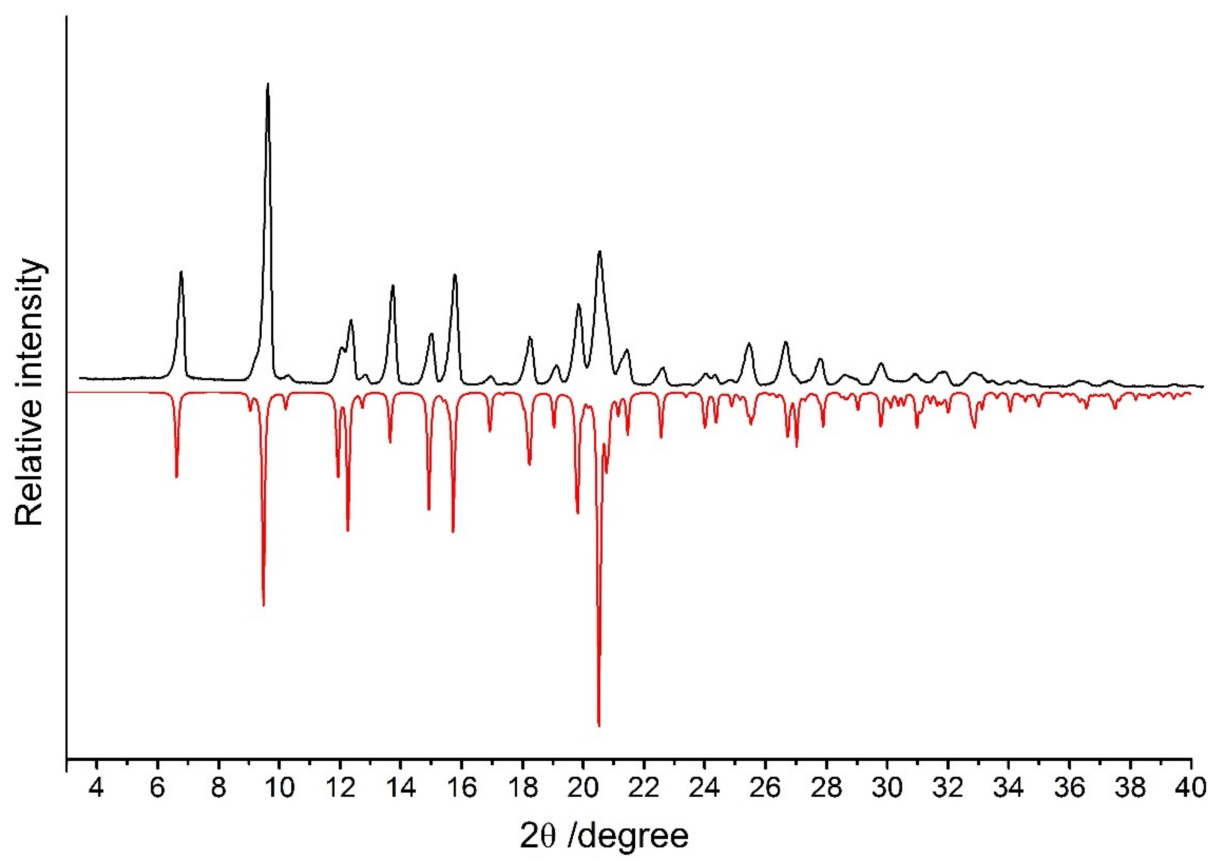

Figure 4. X-ray powder diffraction analysis of 7. Black represented the tested diffraction pattern diagram of intermediate 7 , red represented the simulated diffraction pattern using Mercury 3.9 software.

\subsection{Verification the Activity of GLYX-13 on Cortical Neurons}

To investigate the effect of GLYX-13 on native NMDA receptors, we performed whole-cell voltage-clamp recordings in mice primary cortical neurons to measure NMDAR-mediated currents $\left(I_{\text {NMDA }}\right)$ in the presence of $100 \mu \mathrm{M}$ NMDA without or with $30 \mu \mathrm{M} \mathrm{GLYX-13.} \mathrm{The} \mathrm{results} \mathrm{indicated} \mathrm{that}$ $100 \mu \mathrm{M}$ NMDA alone induced an $I_{\mathrm{NMDA}}$ with a mean amplitude of $7.26 \pm 4.14 \mathrm{pA}(n=7)$, however, co-application of $100 \mu \mathrm{M}$ NMDA and $30 \mu \mathrm{M}$ GLYX-13 significantly increased the plateau responses of $I_{\mathrm{NMDA}}$ to $184.32 \pm 17.26 \mathrm{pA}(n=7)$ (Figure $\left.5 \mathrm{~A}, \mathrm{~B}\right)$. To quantitatively understand the activation

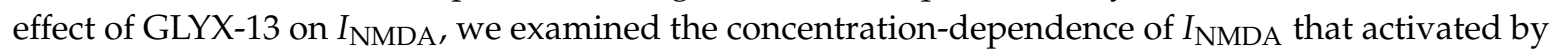
$100 \mu \mathrm{M}$ NMDA with different concentrations of GLYX-13 (Figure 5C,D). The results showed that the synthesized GLYX-13 significantly potentiated native NMDA receptors in a dose-dependent manner, and higher concentration of GLYX-13 on INMDA performed a decrease trend. GLYX-13 potentiated plateau response of $I_{\mathrm{NMDA}}$ in a dose-dependent manner which was consistent with previous reported findings [50].

A

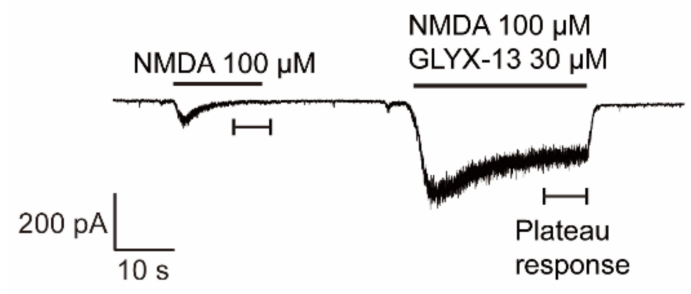

B

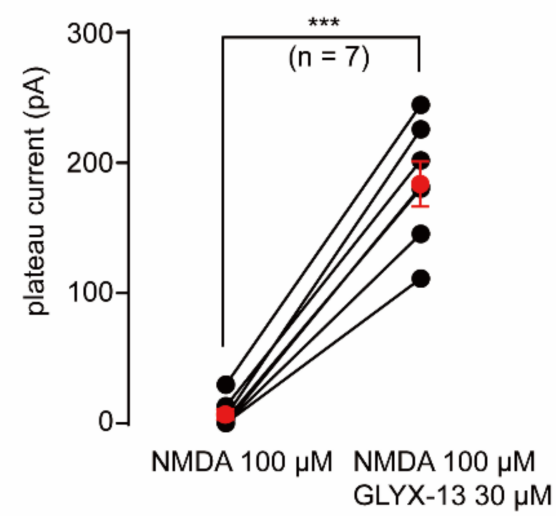

Figure 5. Cont. 
C $100 \mu \mathrm{M}$ NMDA

+ GLYX-13

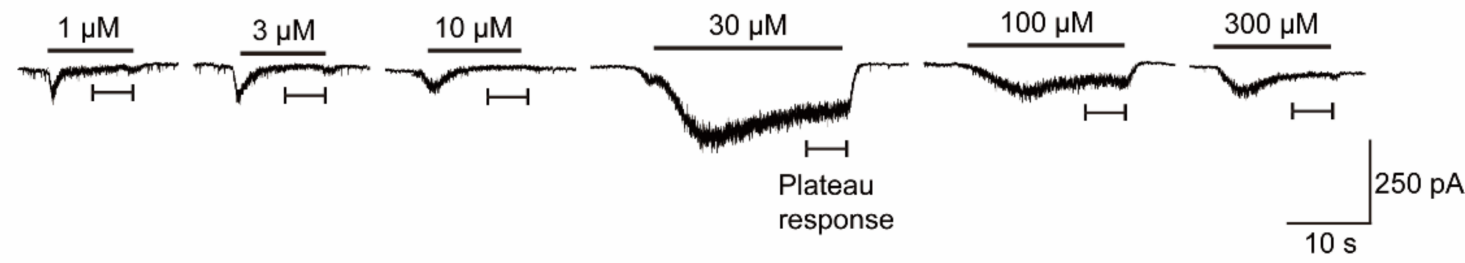

D

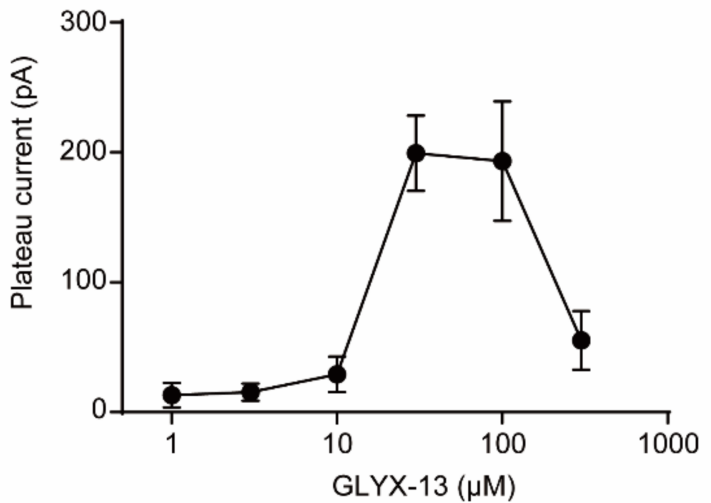

Figure 5. GLYX-13 potentiated responses of NMDA receptors in mice primary cortical neurons. (A) Inward $I_{\text {NMDA }}$ were activated by application of $100 \mu \mathrm{M}$ NMDA and co-application of $100 \mu \mathrm{M}$ NMDA and $30 \mu \mathrm{M}$ GLYX-13; (B) Mean and standard error (shown in red) of whole cell $I_{\mathrm{NMDA}}$ in the presence of $100 \mu \mathrm{M}$ NMDA and $100 \mu \mathrm{M}$ NMDA together with $30 \mu \mathrm{M}$ GLYX-13. Black circles illustrated $I_{\mathrm{NMDA}}$ from individual experiments. ${ }^{* * *} p<0.001$, paired two-tailed Student's $t$-test; (C) Inward NMDAR-mediated currents were activated by application of $100 \mu \mathrm{M}$ NMDA with six different concentrations of GLYX-13; (D) Concentration-response curve for the effect of GLYX-13 on NMDA receptors. Data were represented as mean \pm s.e.m.

\section{Materials and Methods}

\subsection{General Information}

TLC was performed on silica gel GF254 plates (Qingdao Haiyang Chemical Co., Ltd., Qingdao, China). Compounds were visualized by irradiation with UV light or by treatment with $0.05 \mathrm{~g} / \mathrm{mL}$ ninhydrin in ethanol or potassium iodide reagent. ${ }^{1} \mathrm{H}-\mathrm{NMR}$ and ${ }^{13} \mathrm{C}-\mathrm{NMR}$ were recorded on a Bruker Avance-400 MHz instrument (Bruker BioSpin AG, Fällanden, Switzerland). HRMS were obtained with a LC-ESI-Q-TOF-MS apparatus (Waters, Milford, MA, USA). HPLC analysis of GLYX-13 was performed on an Agilent LC 1100 system (Agilent Technologies Inc., Santa Clara, CA, USA) equipped with a diode array detector. Chiral analysis of intermediate were carried out using a Shimadzu LC 20AD system (SIMADZU, Kyoto, Japan) with a SPD-20A UV detector or an Agilent LC 1100 system equipped with a diode array detector. Single crystal diffraction analysis of 7 was performed on a MicroMax-003 (Rigaku Corporation, Tokyo, Japan) X-ray single crystal diffractometer and powder diffraction analysis of 7 was performed by a Bruker D8 FOCUS powder diffractometer (Bruker BioSpin AG, Fällanden, Switzerland). The L-amino acids (protected or free) were obtained from GL Biochem Ltd. (Shanghai, China). Other reagents were provided by Aladdin (Shanghai, China). The organic solvents were commercially available products (Lingfeng Chemical Reagent Co., Ltd., Shanghai, China) and were used without further purification. 


\subsection{Synthesis}

\subsection{1. $\mathrm{Thr}-\mathrm{NH}_{2} \cdot \mathrm{HCl}(\mathbf{1 b})$}

$\mathrm{N}-\mathrm{Cbz}-\mathrm{ThrNH}_{2}(504 \mathrm{~g}, 2 \mathrm{~mol})$ was dissolved in methanol, followed by addition of $10 \%$ of Pd/C $(50.4 \mathrm{~g}, 10 \mathrm{wt} \%)$, and the resulting suspension was stirred at room temperature under hydrogen (1.0 MPa) for $12 \mathrm{~h}$. Pd/C was filtered and the filtrate was evaporated in vacuum to furnish the crude product as yellowish oily liquid, which was redissolved in $3 \mathrm{~L}$ of acetone, followed by slow addition of a solution of $\mathrm{HCl}$ in $\mathrm{PrOH}(500 \mathrm{~mL})$ at $0-5{ }^{\circ} \mathrm{C}$ under stirring. The precipitated white solid was filtered and dried under high vacuum $\left(45^{\circ} \mathrm{C}, 0.1 \mathrm{MPa}\right)$ to afford $1 \mathrm{~b} 289 \mathrm{~g}(93.5 \%$ yield $) .{ }^{1} \mathrm{H}-\mathrm{NMR}(400 \mathrm{MHz}$, $\left.\mathrm{D}_{2} \mathrm{O}\right) \delta 4.15(\mathrm{p}, J=6.1 \mathrm{~Hz}, 1 \mathrm{H}), 3.86(\mathrm{~d}, J=5.2 \mathrm{~Hz}, 1 \mathrm{H}), 1.25(\mathrm{~d}, J=6.5 \mathrm{~Hz}, 3 \mathrm{H}) .{ }^{13} \mathrm{C}-\mathrm{NMR}(101 \mathrm{MHz}$, $\left.\mathrm{D}_{2} \mathrm{O}\right) \delta 170.25,66.04,58.40,18.80$. HRMS (ESI-TOF+) $m / z\left([\mathrm{M}+\mathrm{H}]^{+}\right)$, calcd. for $\mathrm{C}_{4} \mathrm{H}_{11} \mathrm{~N}_{2} \mathrm{O}_{2}+\mathrm{H}^{+}$: 119.0815, found 119.0817 .

\subsubsection{Fmoc-Pro- $\mathrm{ThrNH}_{2}(2 \mathrm{~b})$}

A four-necked flask was charged with a solution of Fmoc-Pro-OH (337 g, $1 \mathrm{~mol})$ in DMF containing NMM (101 g, $1 \mathrm{~mol})$ under nitrogen, which was cooled to $-20^{\circ} \mathrm{C}$, IBCF was added dropwise to the reaction vessel while maintaining the reaction mixture below $-15^{\circ} \mathrm{C}$. 1 was added as solids in one portion to the reaction mixture at the same temperature, followed by dropwise addition of NMM (101 $\mathrm{g}, 1 \mathrm{~mol})$. After the completion of the addition, the reaction mixture was gradually warmed to room temperature. $1 \mathrm{~L}$ of water was poured into the reaction mixture under vigorous stirring, followed by addition of the seed crystal resulting in white solid formed, which was then filtered and dried with oven to afford $2585 \mathrm{~g}$ (89.2\% yield). ${ }^{1} \mathrm{H}-\mathrm{NMR}$ (400 MHz, DMSO-d 6 ) $\delta 7.98-7.56$ (m, 5H), 7.50-7.29 $(\mathrm{m}, 4 \mathrm{H}), 7.14(\mathrm{~m}, 2 \mathrm{H}), 4.86(\mathrm{dd}, J=18.2,5.3 \mathrm{~Hz}, 1 \mathrm{H}), 4.58-4.13(\mathrm{~m}, 4 \mathrm{H}), 4.13-3.94(\mathrm{~m}, 2 \mathrm{H}), 3.56-3.36$ $(\mathrm{m}, 2 \mathrm{H}), 2.31-1.76(\mathrm{~m}, 4 \mathrm{H}), 1.00(\mathrm{dd}, J=14.9,6.3 \mathrm{~Hz}, 3 \mathrm{H}) .{ }^{13} \mathrm{C}-\mathrm{NMR}\left(101 \mathrm{MHz}, \mathrm{DMSO}-d_{6}\right) \delta 172.64$, $172.39,154.80,144.38,141.23,128.17,127.67,125.64,120.58,67.17,66.89,60.54,60.42,58.41,47.09,24.46$, 23.46, 20.53. HRMS (ESI-TOF+) $m / z\left([\mathrm{M}+\mathrm{H}]^{+}\right)$, calcd. for $\mathrm{C}_{24} \mathrm{H}_{27} \mathrm{~N}_{3} \mathrm{O}_{5}+\mathrm{H}^{+}$: 438.4960, found 438.2026.

\subsubsection{Pro-ThrNH 2 (3)}

Compound 2 (437 g, $1 \mathrm{~mol}$ ) was dissolved in TBA (3 L) containing $\mathrm{C}_{8}-\mathrm{SH}$ (435 mL, $2.5 \mathrm{~mol}$ ), and the reaction mixture was stirred at room temperature for $30 \mathrm{~min}$. Next $6 \mathrm{~L}$ of EtOAc was poured into the reaction mixture under vigorous stirring resulting in the precipitation of product, which was filtered and dried under high vacuum $\left(45^{\circ} \mathrm{C}, 0.1 \mathrm{MPa}\right)$. The product was purified by recrystallization from ethyl acetate/EtOH (1:1) to afford $3206 \mathrm{~g}$ (95.8\% yield). ${ }^{1} \mathrm{H}-\mathrm{NMR}\left(400 \mathrm{MHz}, \mathrm{D}_{2} \mathrm{O}\right) \delta 4.24-4.06$ $(\mathrm{m}, 2 \mathrm{H}), 3.80-3.66(\mathrm{~m}, 1 \mathrm{H}), 2.97-2.73(\mathrm{~m}, 2 \mathrm{H}), 2.07(\mathrm{~s}, 1 \mathrm{H}), 1.68(\mathrm{~d}, J=3.2 \mathrm{~Hz}, 2 \mathrm{H}), 1.10(\mathrm{dd}, J=6.2$, $2.5 \mathrm{~Hz}, 3 \mathrm{H}) .{ }^{13} \mathrm{C}-\mathrm{NMR}\left(101 \mathrm{MHz}, \mathrm{D}_{2} \mathrm{O}\right) \delta 177.58,174.58,66.97,59.99,58.45,46.45,30.35,25.27,18.78$. HRMS (ESI-TOF+) $m / z\left([\mathrm{M}+\mathrm{H}]^{+}\right)$, calcd. for $\mathrm{C}_{9} \mathrm{H}_{17} \mathrm{~N}_{3} \mathrm{O}_{3}+\mathrm{H}^{+}:$216.1270, found 216.1342.

\subsubsection{Fmoc-Thr( $\left.{ }^{\mathrm{t}} \mathrm{Bu}\right)-\mathrm{Pro}-\mathrm{OH}(5)$}

A four-necked flask was charged with a solution of Fmoc-Thr $\left({ }^{\mathrm{t}} \mathrm{Bu}\right)-\mathrm{OH}(397 \mathrm{~g}, 1 \mathrm{~mol})$ in THF containing imidazole $(68 \mathrm{~g}, 1 \mathrm{~mol})$ under nitrogen, which was cooled to $-20^{\circ} \mathrm{C}, \mathrm{PivCl}$ was added dropwise while maintaining the reaction mixture below $-15^{\circ} \mathrm{C}$. Pro-OBzl $\cdot \mathrm{HCl}$ was dissolved in $\mathrm{DCM}$ containing imidazole $(68 \mathrm{~g}, 1 \mathrm{~mol})$ and then the obtained solution was added dropwise to the reaction mixture at the same temperature. After the completion of the addition, the reaction mixture was allowed to stir at room temperature. After the reaction was finished, the reaction mixture was filtered and the filtrate was evaporated in vacuum to afford the crude product as yellowish oily liquid, which was redissolved in EtOAc and washed with water and saturated $\mathrm{NaHCO}_{3}$ solution. The separated organic layer was dried over anhydrous $\mathrm{MgSO}_{4}$, filtered and concentrated under vacuum to afford the crude product as an oily liquid, which was dissolved in $\mathrm{EtOH}$, followed by addition of $\mathrm{Pd} / \mathrm{C}$ and slow addition of $\mathrm{Et}_{3} \mathrm{SiH}$ at $0-10{ }^{\circ} \mathrm{C}$. After the completion of the reaction, the $\mathrm{Pd} / \mathrm{C}$ was filtered and the filtrate was evaporated in vacuum to furnish the crude product as oily liquid, which was 
dissolved in EtOAc. The resulting EtOAc solution was extracted with saturated $\mathrm{NaHCO}_{3}$ solution, and the combined aqueous solution was washed with n-hexane and acidified with diluted hydrochloride aqueous solution resulting in precipitation of product, which was re-extracted with EtOAc. The obtained EtOAc solution was dried over anhydrous $\mathrm{MgSO}_{4}$, filtered and concentrated in vacuum to give the crude product as oily liquid, which was purified by recrystallization from $n$-hexane/EtOH (6:1) to furnish the product as a white solid, which was then dried under vacuum $\left(45^{\circ} \mathrm{C}, 0.1 \mathrm{MPa}\right)$ to afford $5267.5 \mathrm{~g}$ (54\% yield). ${ }^{1} \mathrm{H}-\mathrm{NMR}\left(400 \mathrm{MHz}, \mathrm{CDCl}_{3}\right) \delta 7.79(\mathrm{~d}, J=7.5 \mathrm{~Hz}, 2 \mathrm{H}), 7.62(\mathrm{~d}, J=7.4 \mathrm{~Hz}$, $2 \mathrm{H}), 7.43(\mathrm{t}, J=7.2 \mathrm{~Hz}, 2 \mathrm{H}), 7.33(\mathrm{dd}, J=15.3,7.8 \mathrm{~Hz}, 2 \mathrm{H}), 5.70(\mathrm{~d}, J=7.8 \mathrm{~Hz}, 1 \mathrm{H}), 4.68(\mathrm{~d}, J=7.1 \mathrm{~Hz}$, $1 \mathrm{H}), 4.56-4.47(\mathrm{~m}, 1 \mathrm{H}), 4.40(\mathrm{t}, J=10.0 \mathrm{~Hz}, 2 \mathrm{H}), 4.24(\mathrm{t}, J=6.7 \mathrm{~Hz}, 1 \mathrm{H}), 3.97(\mathrm{dd}, J=16.3,10.5 \mathrm{~Hz}, 2 \mathrm{H})$, 3.80-3.66 (m, 1H), 2.48-1.77 (m, 5H), 1.33-1.02 (m, 12H). ${ }^{13} \mathrm{C}-\mathrm{NMR}\left(101 \mathrm{MHz}, \mathrm{CDCl}_{3}\right) \delta 172.88,171.23$, $155.99,143.90,141.32,127.73,127.06,125.12,120.00,74.92,68.72,67.13,59.76,57.47,48.39,47.18,28.32$, 27.95, 24.92, 19.00. HRMS (ESI-TOF+) $m / z\left([\mathrm{M}+\mathrm{H}]^{+}\right)$, calcd. for $\mathrm{C}_{28} \mathrm{H}_{34} \mathrm{~N}_{2} \mathrm{O}_{6}+\mathrm{H}^{+}: 495.2417$, found 495.2497.

\subsubsection{Fmoc-Thr-Pro-Pro-ThrNH 2 (7)}

A four-necked flask was charged with a solution of 5 (247 g, $0.5 \mathrm{~mol})$ in DMF containing NMM (50.5 g, $0.5 \mathrm{~mol})$ under nitrogen, which was cooled to $-20{ }^{\circ} \mathrm{C}$, PivCl $(60.5 \mathrm{~g}, 0.5 \mathrm{~mol})$ was added dropwise while maintaining internal temperature below $-15^{\circ} \mathrm{C}$. Compound 3 was added as a solid in one portion and then the reaction mixture was allowed to stir at room temperature. After the completion of the reaction, water was poured into the reaction mixture and the resulting mixture was extracted with EtOAc, and the combined organic layers was washed with saturated $\mathrm{NaHCO}_{3}$ solution and dried over anhydrous $\mathrm{MgSO}_{4}$, filtered and concentrated under vacuum to afford the crude product as an oily liquid, which was dissolved in DCM $(500 \mathrm{~mL})$, followed by addition of $\mathrm{ZnBr}_{2}(562.5 \mathrm{~g}$, $2.5 \mathrm{~mol}$ ). The resulting reaction mixture was stirred at room temperature for $12 \mathrm{~h}$. Water was added and the reaction mixture was stirred at room temperature resulting in crystallization of 7, which was filtered and dried with an oven to afford $7228.5 \mathrm{~g}$ (72\% yield). ${ }^{1} \mathrm{H}-\mathrm{NMR}\left(400 \mathrm{MHz}, \mathrm{DMSO}-d_{6}\right) \delta 7.90$ $(\mathrm{d}, J=7.5 \mathrm{~Hz}, 2 \mathrm{H}), 7.75(\mathrm{~d}, J=7.5 \mathrm{~Hz}, 2 \mathrm{H}), 7.38(\mathrm{~m}, 6 \mathrm{H}), 7.09(\mathrm{~d}, J=19.0 \mathrm{~Hz}, 2 \mathrm{H}), 4.68(\mathrm{~m}, 3 \mathrm{H}), 4.46-3.94$ $(\mathrm{m}, 7 \mathrm{H}), 3.90-3.51(\mathrm{~m}, 5 \mathrm{H}), 2.22-1.63(\mathrm{~m}, 8 \mathrm{H}), 1.21-0.92(\mathrm{~m}, 6 \mathrm{H}) .{ }^{13} \mathrm{C}-\mathrm{NMR}\left(101 \mathrm{MHz}, \mathrm{DMSO}-d_{6}\right) \delta$ $172.52,171.77,171.28,169.38,156.52,144.26,141.19,128.10,127.53,125.83,120.56,67.22,66.71,66.20$, $60.15,59.23,58.30,58.06,47.68,47.32,47.12,29.05,28.63,25.04,24.93,20.54,20.10$. HRMS (ESI-TOF+) $m / z\left([\mathrm{M}+\mathrm{H}]^{+}\right)$, calcd. for $\mathrm{C}_{33} \mathrm{H}_{41} \mathrm{~N}_{5} \mathrm{O}_{8}+\mathrm{H}^{+}$: 636.3955, found 636.3024.

\subsubsection{Thr-Pro-Pro-ThrNH 2 (GLYX-13)}

To a suspension of 7 (31.8 g, $0.05 \mathrm{~mol})$ in DMF $(50 \mathrm{~mL})$ was added $\mathrm{C}_{8}-\mathrm{SH}(22 \mathrm{~mL})$ and TBA $(25 \mathrm{~mL})$, and the resulting mixture was vigorously stirred at room temperature for $30 \mathrm{~min}$. EtOAc $(50 \mathrm{~mL}) \mathrm{was}$ poured into the reaction mixture resulting in precipitation of the crude product, which was filtered and dried under high vacuum $\left(45^{\circ} \mathrm{C}, 0.1 \mathrm{MPa}\right)$. The dried crude product was purified by recrystallization from $n$-hexane and EtOH $(160 \mathrm{~mL}, 1: 1)$ to furnish GLYX-13 as a white solid, which was dried in the same manner. Product weight: $20 \mathrm{~g}\left(97 \%\right.$ yield). $[\alpha]_{\mathrm{D}}^{30}=-112.8\left(c=1, \mathrm{H}_{2} \mathrm{O}\right) .{ }^{1} \mathrm{H}-\mathrm{NMR}\left(400 \mathrm{MHz}, \mathrm{D}_{2} \mathrm{O}\right)$ $\delta 4.60(\mathrm{dd}, J=17.6,7.7 \mathrm{~Hz}, 1 \mathrm{H}), 4.41(\mathrm{dd}, J=15.4,9.8 \mathrm{~Hz}, 1 \mathrm{H}), 4.25-4.08(\mathrm{~m}, 2 \mathrm{H}), 3.86-3.35(\mathrm{~m}, 6 \mathrm{H})$, 2.37-2.14 (m, 2H), 2.07-1.70 (m, 6H), 1.20-0.99 (m, 6H). ${ }^{13} \mathrm{C}-\mathrm{NMR}\left(101 \mathrm{MHz}, \mathrm{D}_{2} \mathrm{O}\right) \delta 174.43,173.21$, 172.56, 172.42, 69.31, 67.00, 60.34, 58.79, 58.67, 57.71, 48.20, 47.80, 29.23, 28.21, 26.71, 24.61, 18.79, 18.51. HRMS (ESI-TOF+) $m / z\left([\mathrm{M}+\mathrm{H}]^{+}\right)$, calcd. for $\mathrm{C}_{18} \mathrm{H}_{31} \mathrm{~N}_{5} \mathrm{O}_{6}+\mathrm{H}^{+}:$414.2274, found 414.2121. Analyt. HPLC: $\mathrm{tR}=7.00 \mathrm{~min}(>99 \%)$.

\subsection{Cortical Neuronal Cultures}

Cortical neurons were prepared from neonatal (P0) C57BL/6 mice of either sex. Animals were decapitated and their brains were dissected under a stereo micro-scope. Cortex was dissociated and digested with $0.25 \%$ trypsin (Life Technologies, Framingham, MA, USA) for 30 min at $37^{\circ} \mathrm{C}$. Following trypsinization, DMEM (Life Technologies) supplemented with 10\% FBS (Gemini, Rocklin, CA, USA) 
and DNase solution (Macklin, Shanghai, China) were added. Cells were subsequently dissociated by gentle trituration using a pipette. Cell suspension was collected and then plated onto poly-D-lysine (Sigma-Aldrich Corporation, St. Louis, MO, USA) coated glass coverslips in sterile plastic dishes. After incubation for $4 \mathrm{~h}$ at $37{ }^{\circ} \mathrm{C}$ in a humidified $95 \%$ air $/ 5 \% \mathrm{CO}_{2}$ atmosphere, the medium was changed with Neurobasal Medium supplemented with 2\% B27 and 0.5 mM GlutaMAX-1 (Life Technologies).

\subsection{Whole-Cell Voltage-Clamp Recordings}

Cortical neurons were used for electrophysiological experiments after 7-14 days in vitro. Cultures were transferred to a glass-bottomed recording chamber perfused with the external solution, containing $142 \mathrm{mM} \mathrm{NaCl}, 2.5 \mathrm{mM} \mathrm{KCl}, 2 \mathrm{mM} \mathrm{CaCl} 2,10 \mathrm{mM}$ HEPES, $10 \mathrm{mM}$ Glucose (pH 7.3 with NaOH, $325 \mathrm{mOsm})$. Pipettes had resistances of 5-8 $\mathrm{M} \Omega$ when filled with internal pipette solution, containing $122 \mathrm{mM} \mathrm{CsCl}, 1 \mathrm{mM} \mathrm{CaCl} 2,5 \mathrm{mM} \mathrm{MgCl}_{2}, 10 \mathrm{mM}$ EGTA, $10 \mathrm{mM}$ HEPES, $4 \mathrm{mM} \mathrm{Na} 2$ ATP, $0.3 \mathrm{mM}$ Tris-GTP, 14 mM Tris-phosphocreatinin (pH 7.3 with $\mathrm{CsOH}, 318 \mathrm{mOsm}$ ). Whole-cell current recordings were made from cultured neurons at a holding potential of $-70 \mathrm{mV}$ using a HEKA EPC10 amplifier with the PatchMaster.v2.15 (HEKA, Welwyn Garden, United Kingdom). Series resistance was in the order of $10-30 \mathrm{M} \Omega$ and was approximately $80 \%$ compensated. All recordings were performed at room temperature.

Drugs were diluted from concentrated stock solutions into a modified version of the external solution including $1 \mu \mathrm{M}$ strychnine and $500 \mathrm{nM}$ TTX. Solution switching was achieved with a rapid solution changer (ALA-VW8, New York, NY, USA).

Values of plateau response of NMDA-mediated currents obtained from whole-cell voltage-clamp recordings were calculated and analyzed. Group data were represented as mean \pm s.e.m. Comparisons between two groups were made using Student's paired. Statistical significance of differences at $p<0.05$ is indicated as asterisk $\left(^{*}\right), p<0.01$ is indicated as two asterisk $\left(^{* *}\right)$ and $p<0.001$ is shown with three asterisk $\left(^{* * *}\right)$ in all figures.

\section{Conclusions}

A column chromatography-free solution-phase synthetic route of GLYX-13 has been developed with an optimized coupling strategy. Compared with the original route reported in a patent, the overall yield was significantly improved (from 10-15\% to 30\%), and the work-up procedures were suitable for industrial production. Moreover, the absolute configuration of precursor compound of GLYX-13 was identified by X-ray single crystal diffraction, and the activity of GLYX-13 was verified in the cortical neurons. In summary, all the results indicated that the improved synthetic route of GLYX-13 was economic and scalable and provided the product with good yield and high optical purity.

Supplementary Materials: Supplementary materials are available online. CCDC numbers 1549242 contains the supplementary crystallographic data for this paper. These data can be obtained free of charge via http: / / www.ccdc.cam.ac.uk/conts/retrieving.html (or from the CCDC, 12 Union Road, Cambridge CB2 1EZ, UK; Fax: +44-1223-336033; E-mail: deposit@ccdc.cam.ac.uk). Electronic Supplementary Materials (ESM) available: Table S1, Figures S1-S21.

Author Contributions: L.Z., J.L., Z.H., G.Z. and W.L. designed the research; J.L. and W.L. wrote the manuscript and prepared the data, Figures and Tables; J.L. and Z.L. prepared the Figures; J.L., Y.C. and W.L. synthesized the compounds in the article; M.F. did the measurement of activities; L.Z. commented and revised on the manuscript. All authors reviewed and approved the manuscript.

Acknowledgments: This research was financially supported by National Major Scientific and Technological Special Project for "Significant New Drugs Development" (2018ZX9711002-013-004).

Conflicts of Interest: The authors declare no conflict of interest. 


\section{References}

1. Wang, J.; Jing, L.; Toledo-Salas, J.C.; Xu, L. Rapid-onset antidepressant efficacy of glutamatergic system modulators: The neural plasticity hypothesis of depression. Neurosci. Bull. 2015, 31, 75-86. [CrossRef] [PubMed]

2. Tomasetti, C.; Iasevoli, F.; Buonaguro, E.F.; De Berardis, D.; Fornaro, M.; Fiengo, A.L.; Martinotti, G.; Orsolini, L.; Valchera, A.; Di Giannantonio, M.; et al. Treating the synapse in major psychiatric disorders: The role of postsynaptic density network in dopamine-glutamate interplay and psychopharmacologic drugs molecular actions. Int. J. Mol. Sci. 2017, 18, 135. [CrossRef]

3. Paoletti, P.; Bellone, C.; Zhou, Q. Nmda receptor subunit diversity: Impact on receptor properties, synaptic plasticity and disease. Nat. Rev. Neurosci. 2013, 14, 383-400. [CrossRef] [PubMed]

4. De Berardis, D.; Campanella, D.; Gambi, F.; La Rovere, R.; Carano, A.; Conti, C.M.; Sivestrini, C.; Serroni, N.; Piersanti, D.; Di Giuseppe, B.; et al. The role of c-reactive protein in mood disorders. Int. J. Immunopathol. Pharmacol. 2006, 19, 721-725. [CrossRef]

5. Marini, S.; Vellante, F.; Matarazzo, I.; De Berardis, D.; Serroni, N.; Gianfelice, D.; Olivieri, L.; Di Renzo, F.; Di Marco, A.; Fornaro, M.; et al. Inflammatory markers and suicidal attempts in depressed patients: A review. Int. J. Immunopathol. Pharmacol. 2016, 29, 583-594. [CrossRef] [PubMed]

6. Ghasemi, M.; Phillips, C.; Fahimi, A.; McNerney, M.W.; Salehi, A. Mechanisms of action and clinical efficacy of NMDA receptor modulators in mood disorders. Neurosci. Biobehav. Rev. 2017, 80, 555-572. [CrossRef] [PubMed]

7. Hayley, S.; Litteljohn, D. Neuroplasticity and the next wave of antidepressant strategies. Front. Cell. Neurosci. 2013, 7, 218. [CrossRef] [PubMed]

8. Kato, T.; Fogaca, M.V.; Deyama, S.; Li, X.Y.; Fukumoto, K.; Duman, R.S. BDNF release and signaling are required for the antidepressant actions of GLYX-13. Mol. Psychiatry 2017. [CrossRef] [PubMed]

9. Moskal, J.R.; Burch, R.; Burgdorf, J.S.; Kroes, R.A.; Stanton, P.K.; Disterhoft, J.F.; Leander, J.D. GLYX-13, an NMDA receptor glycine site functional partial agonist enhances cognition and produces antidepressant effects without the psychotomimetic side effects of NMDA receptor antagonists. Expert Opin. Investig. Drugs 2014, 23, 243-254. [CrossRef] [PubMed]

10. Santini, A.C.; Pierantoni, G.M.; Gerlini, R.; Iorio, R.; Olabinjo, Y.; Giovane, A.; Di Domenico, M.; Sogos, C. GLYX-13, a new drug acting on glutamatergic pathways in children and animal models of autism spectrum disorders. BioMed. Res. Int. 2014, 2014, 234-295. [CrossRef] [PubMed]

11. Machado-Vieira, R.; Henter, I.D.; Zarate, C.A. New targets for rapid antidepressant action. Prog. Neurobiol. 2017, 152, 21-37. [CrossRef] [PubMed]

12. Burgdorf, J.; Zhang, X.L.; Weiss, C.; Gross, A.; Boikess, S.R.; Kroes, R.A.; Khan, M.A.; Burch, R.M.; Rex, C.S.; Disterhoft, J.F.; et al. The long-lasting antidepressant effects of rapastinel (GLYX-13) are associated with a metaplasticity process in the medial prefrontal cortex and hippocampus. Neuroscience 2015, 308, $202-211$. [CrossRef] [PubMed]

13. Jin, Z.L.; Liu, J.X.; Liu, X.; Zhang, L.M.; Ran, Y.H.; Zheng, Y.Y.; Tang, Y.; Li, Y.F.; Xiong, J. Anxiolytic effects of GLYX-13 in animal models of posttraumatic stress disorder-like behavior. J. Psychopharmacol. 2016, 30, 1-9. [CrossRef] [PubMed]

14. Moskal, J.R.; Burgdorf, J.; Kroes, R.A.; Brudzynski, S.M.; Panksepp, J. A novel NMDA receptor glycine-site partial agonist, GLYX-13, has therapeutic potential for the treatment of autism. Neurosci. Biobehav. Rev. 2011, 35, 1982-1988. [CrossRef] [PubMed]

15. Weiguo, S.; Bohua, Z.; Shiyan, F.; Yishan, Y. Process for Preparation of H-Thr-Pro-Pro-Thr-Nh 2 Peptide by Liquid-Phase Synthesis Method. CN 104109189A, 22 October 2014.

16. McDermott, T.S.; Bhagavatula, L.; Borchardt, T.B.; Engstrom, K.M.; Gandarilla, J. Scalable synthesis of dipeptidyl peptidase-4 inhibitor ABT-279. Org. Process Res. Dev. 2009, 13, 1145-1155. [CrossRef]

17. Chulin, A.N.; Rodionov, I.L.; Baidakova, L.K.; Rodionova, L.N.; Balashova, T.A.; Ivanov, V.T. Preparation and reactivity of aminoacyl pyroglutamates. Facile synthesis of 10-membered-ring cyclic dipeptides derived from 1,4-diaminobutyric and glutamic acids. J. Pept. Sci. 2005, 11, 175-186. [CrossRef] [PubMed]

18. Sun, H.L.; He, B.F.; Xu, J.X.; Wu, B.; Ouyang, P. Efficient chemo-enzymatic synthesis of endomorphin-1 using organic solvent stable proteases to green the synthesis of the peptide. Green Chem. 2011, 13, 1680-1685. [CrossRef] 
19. Kudryavtsev, K.V.; Shulga, D.A.; Chupakhin, V.I.; Sinauridze, E.I.; Ataullakhanov, F.I.; Vatsadze, S.Z. Synthesis of novel bridged dinitrogen heterocycles and their evaluation as potential fragments for the design of biologically active compounds. Tetrahedron 2014, 70, 7854-7864. [CrossRef]

20. Arnett, E.M.; Miller, J.G.; Day, A.R. Effect of structure on reactivity.1 iii. Aminolysis of esters with primary amines. J. Am. Chem. Soc. 1950, 72, 5635-5638. [CrossRef]

21. Gordon, M.; Miller, J.G.; Day, A.R. Effect of structure on reactivity. Ii. Influence of solvents on ammonolysis of esters. J. Am. Chem. Soc. 1949, 71, 1245-1250. [CrossRef]

22. Gordan, M.; Miller, J.G.; Day, A.R. Effect of structure on reactivity. I. Ammonolysis of esters with special reference to the electron release effects of alkyl and aryl groups. J. Am. Chem. Soc. 1948, 70, 1946-1953. [CrossRef]

23. Marco, R.D.; Di Gioia, M.L.; Leggio, A.; Liguori, A.; Perri, F.; Siciliano, C.; Viscomi, M.C. A new non-natural arginine-like amino acid derivative with a sulfamoyl group in the side-chain. Amino Acids 2010, 38, 691-700. [CrossRef]

24. Flegel, M.; Flegelova, Z.; Malon, P.; Klenerova, V.; Hynie, S. Fmoc deprotection by tert-butylamine and its comparison in solution and solid phase synthesis. Collect. Symp. Ser. 2011, 13, 41-44.

25. Leggio, A.; Liguori, A.; Napoli, A.; Siciliano, C.; Sindona, G. New strategies for an efficient removal of the 9-fluorenylmethoxycarbonyl (Fmoc) protecting group in the peptide synthesis. Eur. J. Org. Chem. 2000, 573-575. [CrossRef]

26. Maegawa, T.; Fujiwara, Y.; Ikawa, T.; Hisashi, H.; Monguchi, Y.; Sajiki, H. Novel deprotection method of Fmoc group under neutral hydrogenation conditions. Amino Acids 2009, 36, 493-499. [CrossRef] [PubMed]

27. Stefan, H.; Roger, M.; Rainer, R.; Simeunovic, M. Thermal cleavage of the Fmoc protection group. Chimia 2010, 64, 200-202.

28. Tana, G.; Kitada, S.; Fujita, S.; Okada, Y.; Kim, S.; Chiba, K. A practical solution-phase synthesis of an antagonistic peptide of TNF- $\alpha$ based on hydrophobic tag strategy. Chem. Commun. 2010, 46, 8219-8221. [CrossRef] [PubMed]

29. Sheppeck, J.E. A convenient and scaleable procedure removing the Fmoc group in solution. Tetrahedron Lett. 2000, 41, 5329-5333. [CrossRef]

30. Suhas, R.; Gowda, D.C. Design and synthesis of tryptophan containing peptides as potential analgesic and anti-inflammatory agents. J. Pept. Sci. 2012, 18, 535-540. [CrossRef]

31. Yao, J.; Liu, H.; Zhou, T.; Chen, H.; Miao, Z.; Dong, G.; Wang, S.; Sheng, C.; Zhang, W. Total synthesis and structure-activity relationships of caspofungin-like macrocyclic antifungal lipopeptides. Tetrahedron 2012, 68, 3074-3085. [CrossRef]

32. Yao, J.; Liu, H.; Zhou, T.; Chen, H.; Miao, Z.; Sheng, C.; Zhang, W. Total synthesis and structure-activity relationships of new echinocandin-like antifungal cyclolipohexapeptides. Eur. J. Med. Chem. 2012, 50, 196-208. [CrossRef]

33. Zhang, T.; Chen, Z.X.; Yan, T.; Han, B.; Zhang, N.; Song, W.; Liu, Z.L.; Zhao, J.L.; Liu, J.L. Kilogram-scale synthesis of osteogenic growth peptide (10-14) using a fragment coupling approach. Org. Process Res. Dev. 2015, 19, 1257-1262. [CrossRef]

34. Nizar, H.; Bo, Q.; Heewon, L.; Lorenz, J.; Varsolona, R.; Kapadia, S.; Sarvestani, M.; Feng, X.W.; Busacca, C.A.; Hebrault, D.; et al. Pat application in the expedited development of a three-step, one-stage synthesis of the dipeptide intermediate of hcv protease inhibitor faldaprevir. Org. Process Res. Dev. 2015, 19, 132-138.

35. Wakasugi, K.; Akira, L.; Misaki, T.; Nishii, Y.; Tanabe, Y. Simple, mild, and practical esterification, thioesterification, and amide formation utilizingp-toluenesulfonyl chloride andn-methylimidazole. Adv. Synth. Catal. 2003, 345, 1209-1214. [CrossRef]

36. Rayle, H.L.; Fellmeth, L. Development of a process for triazine-promoted amidation of carboxylic acids. Org. Process Res. Dev. 1999, 3, 172-176. [CrossRef]

37. Myers, A.G.; Gleason, J.L.; Yoon, T.; Daniel, W.K. Highly practical methodology for the synthesis of D- and L-r-amino acids, $N$-protected r-amino acids, and N-methyl-r-amino acids. J. Am. Chem. Soc. 1997, 119, 656-673. [CrossRef]

38. Venalainen, J.I.; Wallen, E.A.; Poso, A.; Garcia-Horsman, J.A.; Mannisto, P.T. Synthesis and characterization of the novel fluorescent prolyl oligopeptidase inhibitor 4-fluoresceinthiocarbamoyl-6-aminocaproyl-L-prolyl-2(s)-(hydroxyacetyl)pyrrolidine. J. Med. Chem. 2005, 48, 7093-7095. [CrossRef] [PubMed] 
39. Noda, K.; Oda, M.; Sato, M.; Yoshida, N. A facile method for the preparation of t-butyloxycarbonyl amino acid p-nitroanilides. Int. J. Pept. Protein Res. 1990, 36, 197-200. [CrossRef] [PubMed]

40. Ho, G.J.; David, J.M. Lithium-initiated imide formation. A simple method for $N$-acylation of 2-oxazolidinones and bornane-2,10-sultam. J. Org. Chem. 1995, 60, 2271-2273. [CrossRef]

41. Ryakhovsky, V.V.; Ivanov, A.S. Study of intramolecular aminolysis in peptides containing $N$-alkylamino acids at position 2. Tetrahedron 2012, 68, 7070-7076. [CrossRef]

42. Shevchenko, V.P.; Nagaev, I.Y.; Alfeeva, L.Y.; Andreeva, L.A.; Shevchenko, K.V.; Myasoedov, N.F. Synthesis of Tyr-Pro-Phe-Val-Glu-L-[3,4- $\left.{ }^{3} \mathrm{H}\right]$ Pro-Ile, Tyr-D-Ala-Phe-Gly-Tyr-L-[3,4- $\left.{ }^{3} \mathrm{H}\right]$ Pro-Ser-NH${ }_{2}$, and Tyr-D-Ala-Phe-Gly-Tyr-D-[3,4- $\left.{ }^{3} \mathrm{H}\right]$ Pro-Ser- $\mathrm{NH}_{2}$, labeled analogs of human $\beta$-casomorphin and dermorphin. Radiochemistry 2004, 46, 63-71. [CrossRef]

43. McMurray, J.S.; Mandal, P.K. Pd-c-induced catalytic transfer hydrogenation with triethylsilane. J. Org. Chem. 2007, 72, 6599-6601.

44. Martinez, J.; Tolle, J.C.; Miklos, B. Side reactions in peptide synthesis. 12. Hydrogenolysis of the 9-fluorenylmethyloxycarbonyl group. J. Org. Chem. 1979, 44, 3596-3598. [CrossRef]

45. Somlai, C.; Lovas, S.; Forgo, P.; Murphy, R.F.; Penke, B. Dehydration of threonineine esters during tosylation. Synth. Commun. 2001, 31, 3633-3640. [CrossRef]

46. Mirza-Aghayan, M.; Boukherroub, R.; Bolourtchian, M. A mild and efficient palladium-triethylsilane system for reduction of olefins and carbon-carbon double bond isomerization. Appl. Organomet. Chem. 2006, 20, 214-219. [CrossRef]

47. Wu, Y.Q.; Limburg, D.C.; Wilkinson, D.E.; Mark, J.V.; Hamilton, G.S. A mild deprotection procedure for tert-butyl esters and tert-butyl ethers using $\mathrm{ZnBr}_{2}$ in methylene chloride. Tetrahedron Lett. 2000, 41, 2847-2849. [CrossRef]

48. Bryan, L.; Berliner, M.; Buzon, R.; Stephen, T.C.; Kaneko, T.; Keene, N.; Kissel, W.; Tung, L.; Leeman, K.R. Aqueous phosphoric acid as a mild reagent for deprotection of tert-butyl carbamates, esters, and ethers. J. Org. Chem. 2006, 71, 9045-9050.

49. Bartoli, G.; Bosco, M.; Carlone, A.; Locatelli, M.; Marcantoni, E.; Melchiorre, P.; Sambri, L. Tert-butyl ethers: Renaissance of an alcohol protecting group. Facile cleavage with cerium(iii) chloride/sodium iodide. Adv. Synth. Catal. 2006, 348, 905-910. [CrossRef]

50. Moskal, J.R.; Kuo, A.G.; Weiss, C.; Wood, P.L.; O'Connor Hanson, A.; Kelso, S.; Harris, R.B.; Disterhoft, J.F. GLYX-13: A monoclonal antibody-derived peptide that acts as an $N$-methyl-D-aspartate receptor modulator. Neuropharmacology 2005, 49, 1077-1087. [CrossRef]

Sample Availability: Samples of the compounds are available from the authors.

(C) 2018 by the authors. Licensee MDPI, Basel, Switzerland. This article is an open access article distributed under the terms and conditions of the Creative Commons Attribution (CC BY) license (http:/ / creativecommons.org/licenses/by/4.0/). 